\title{
OBJECTIVITY OF TEACHERS' PEDAGOGICAL ACTIVITY IN THE LEARNING PROCESS
}

The aim of the research is to focus on the objectivity of teachers' pedagogical activity in the learning process at universities and to show the connection of this problem with philosophical teaching. The methodological basis of the study is the basic principles of philosophy on dialectical relationships, the interdependence of phenomena and processes of socio-pedagogical activities, the role of the individuality in the development of its material and spiritual foundations. The research uses a systematic approach to identify the scale, complexity, integrity and dynamics of the study of the objectivity of pedagogical activities of teachers in the learning process.

Keywords: objectivity, reformation, teacher's activity, students' knowledge level quality, education, Higher Learning Institution, assessment.

Introduction. There is amount of scientific literature devoted to the problem of pedagogic activity, but the justice comprehension in the assessment process of students' knowledge level quality remains an essential necessity. It should be emphasized that education has always combined the most important tasks in achieving the three-fold goal: the knowledge of the nature mysteries and its laws, the training of specialists for useful work and their education. That's why the education system reforms raise the need for highly qualified training of modern specialists; it needs to improve the process of pedagogical assessment the knowledge, in particular, updating the education system and specialists' training.

One of the important pedagogic principles for assessment the students' knowledge level is the objectivity, which determines the effectiveness of the whole process of pedagogic evaluation. Because of the absence or the falsity of objectivity, the greatest misunderstandings arise, and stimulation in the subject study is violated. Non-objective assessment forms indifference to the knowledge acquisition, generates a desire for superficial assimilation and creates a psychological barrier to obtain a higher grade.

The aim of research is to focus on the objectivity of teachers' pedagogical activity in the learning process at universities, underline the objectivity in the teacher's pedagogic activity and show the connection this problem with philosophical teaching.

This problem is studied by G. P. Vasyanovych. The idea of objectivity was developed by Greek philosopher Plato, Thomas Aquinas, Mark Tullia Cicero, Confucius, G. Hegel.

The methodological basis of the study is the initial provisions of philosophy on the dialectical relationship, the interdependence of phenomena and processes of sociopedagogical activities, the role of the individual in the development of its material and spiritual foundations.

Presentation of the main positions. The assessment becomes an effective learning incentive when it is fair, objectively follows the same requirements for all students. It is especially important that students feel and recognize the fairness, goodwill of the teacher and have seen the real level of their knowledge. Grades of success should not depend on those or other peculiarities of students' behavior or personal misunderstandings with teachers, which often happens in pedagogic practice.

In particular, the Greek philosopher Plato emphasized that justice is integrity, that is to say, the right attitude to other people, and expressed the opinion that in their beginnings all people were equal, only later, abusing their power, began to violate the fair laws of equality. He emphasizes that justice is a manifestation of holiness and that holiness is just justice. Hence, justice is an extremely high ideal that cannot be achieved in the real life, as in general, but ideals exist to discipline our goal in a bright and clean daily struggle of
Good and Evil. In order to grasp the ideal, or even to approach it, one must try to keep his light in the spectrum of our soul constantly in a clean, unpolluted, undignified sense of envy and revenge, so that it constantly strengthens the flame of love and charity. He highlights that mind, our conscious awareness, is the part that thinks, analyzes, looks ahead, rationally weighs options, and tries to gauge what is best and truest overall and what is ideal and justice [Plato's tripartite..., 2018].

So, in order to be fair, we should study the problem deeply and understand its essence, be able to put yourself in the place of another, to follow the advice of the Chinese philosopher Confucius (551-479 BC. e.) who stated that there was no need to do something else for someone that we did not want anything that to be done for us. He calls for being objective and faithful in all our deeds and words. According to the teacher of the Chinese nation, a noble man, a fair man is a morally perfect person who searches for his moral purpose throughout life, asserts objectiveness. Important in the teachings of Confucius is the personal virtues of man: "generosity is acquired by people, responsibility generates trust; diligence guarantees success; Kindness can eventually change and educate people" [Political Theory..., 2018].

Confucius taught of how one is to govern themselves, and how the state is to govern society. The ways of governing can be seen in the traditions of forefathers. By returning to these, society can be virtuous and harmonious. Government is seen as a tool to help bring out the best of its people. Confucius saw it as responsible for the wellbeing of its citizens but insists that they not forget their individual roles themselves. In order to properly carry out its role, government must be looked upon by its people for leadership and be respected. It must not lose the faith of its people [Political Theory..., 2018].

G. V. Vasyanovych highlights that this sensation does not include evaluation, but does not deny justice, on the contrary, mercy is the highest and last form of justice. We absolutely agree with this teaching because we really cannot appreciate the law sensation, we only see the actions that show the attitude to the justice. Thus, studying the activities of the teacher's teaching activities is an opportunity to appreciate his sense of rights and objectivity [Vasyanovych, 2005].

The objectivity is covered in this parable. There was a temple in a small village where was a great Crucifixion of Jesus Christin in its center. People came to God with different intentions, who to ask, who to thank, and who just to pray. One day, an old man came to this temple, seeing Jesus on the cross and said: "God, you are so hard to tolerate, I would like to swap places with you, and at least for one day, make your patience easier." Then suddenly he spoke from the Crucifixion. Jesus said to him: "Well, but I will 
have one requisition, so that you cannot see or not hear it here, you must keep silent." "I agree with this requisition; I will keep silent." So the man exchanged places with Jesus. There were lots of different people, he heard a lot of requests, thanks, complaints ... Almost at the end of the day a very rich man came to that temple with a bag of gold. He prayed very quickly and went out in a hustle, forgetting a bag of gold on the temple bench. Then, the very poor man followed by the rich one, asking God for help, only he started $\ldots$ and then he saw the bag on the temple bench, looked around and surprised that so soon God heard him and rushed home. Then the young boy went to the temple to ask for a happy journey to come back home by the ship. He only began to pray as his prayer was interrupted because that rich man returned with the police and he was sure that this young man had taken his gold. The boy began to beg, but it was all in vain ... Then a man from the Crucifixion shouted: "It is not true, he did not take gold." And he told all the truth: the boy was let go and the police went to seek the poor man. When there was nobody in the temple, Jesus came in and said: "Stairs from there, you are not worthy to hang here. You did not keep your promise." "But God, is it fair to judge an innocent person. So do not be "- the man replied." "And how do you know how it should be. This is GOD WILL! This rich man had to lose gold, as he intends to use it for very bad purposes. The poor man had to find that bag with gold because he has not possibility and has got nothing for feeding his large family, and the guy who was let go should not have time to catch the ship, which is now buried in the sea".

A vivid example of justice makes us think over the teacher's actions, because objectiveness is one of the important characteristics of a teacher who conducts an education process. The teacher's fairness, his/her objective attitude to the students during the education process, students appreciate the teacher's objectiveness, because justice requires a careful and attentive attitude towards students. It is logical that a teacher presents to some students more sympathy and affection than to others because they have different the knowledge quality levels, readability, speed educational material perception, etc. The essence of justice is that there is no unfair and impartial attitude towards students who are less cute teachers, because this will lead to the subject superficial mastering, and unwillingness to attend the education process.

The teacher should be fair and objective in the process of pedagogic activity, particularly in the process of assessment the students' knowledge level. He/she should be an example for students and do not have any contradictions with his/her personality, in particular not to be late for classes, to prepare the lectures and seminars in good faith, not to deviate from the specified period of task checking performed by students. Then it is possible to demand from students the integrity in mastering the studying subject, perfectly done the home assignment, timely entry into the classes. If the teacher does not adhere to these rules and violates them, then his controversy will be very quickly detected by the students and they will definitely give a negative profile to that teacher. Thus, the lack of justice and objectivity in relation to students will undermine the teacher's authority, his/her image and hinder his/her success.

It is important for students to be convinced of the teacher's fairness, his/her qualification and professionalism, because of the lack objectivity or the falsity, there is the greatest misunderstanding between students and lecturer, and stimulation in the subject studying is violated. Objectivity and injustice towards the students usually forms an indifference to the knowledge acquisition, generates a desire for superficial assimilation and creates a psychological barrier for obtaining solid knowledge. Definition of the knowledge quality level, in particular the grades result presented by the teacher, become an effective stimulus when they are presented fairly, objectively and proceeding from the same requirements to all students. It is very important that students feel and recognize the teacher's fairness, his/her goodwill and see the real level of their knowledge. The grades of success should not depend on those or other peculiarities of students' behavior or personal misunderstandings with teachers, which often happens in the pedagogic activity [Zvarych, 2015].

The problem of assessment students' knowledge level in the system of higher education was and remains one of the most important in the pedagogic theory and practice. Its content covers a wide range of issues throughout the education process, touching at the same time the question of the teacher's high responsibility for his/her objectivity and fairness of the assessments. There is always a peculiar aspect of objective and subjective in the process of assessment students' knowledge level. The main figure in the assessment process is and was the lecturer, from his/her culture and knowledge always depends on the optimal version of evaluation, which spiritually supports the student in mastering the knowledge, in self-perfection. The German philosopher Georg Wilhelm Friedrich Hegel is one of the greatest systematic thinkers in the history of Western philosophy, noted: "The due act is the sacred principle of any justice, the basis of any state system. Jesus does not demand a complete abandonment of the right, thus raising over the whole sphere of justice or justice through love, in which, along with the law, disappears and the feeling of inequality, and the possibility of this feeling, which causes the establishment of equality, that is, the disappearance of hatred of enemies" [Hegel, 1976, c. 101]. At the core of Hegel's social and political thought are the concepts of freedom, reason, self-consciousness, and recognition.

One person's arbitrariness is limited to society in order to defend the weaker, not to lose the integrity of the citizens interests. There are rights, laws, demands: "This is impossible!", "This is not yours!" And so on. Thus, the term "law" is used in many ways - social, philosophical, every day, and legal. All these transformations take place under the slogan of justice. It is known that the Latin name "justice" (right) means the combination of law and justice. It follows that justice is a law sensation.

The Ukrainian folklore provides a narration and an instructive account of objectivity. Once the donkey, the fox and the lion, agreed to live with such a union that they would divide the spoil that each of them would win. Donkey, when it was its turn to divide the prey, thinking that he/she donkey was equal to a lion, divided into two parts. The lion could not bear it, he/she lion threw on the donkey and rented it. Then it was a fox turn to divide the prey. But she, like a wise and cunning beast, realized what was being waiting for her. She left for itself just a little piece of prey, leaving the rest of it to the lion. The lion praised her and asked, "Fox, who taught you to do this?" He/She answered, "An adventure that happened with the donkey." This story reveals the natural significance of the strong and weak, the sensual tact of empathy (the fox), the primitiveness of the inner world (donkey), strength and arrogance, justice, the more powerful of law sensation (lion).

Research results and discussion. The research has been carried out at Kyiv National University of Trade and Economics. The results are presented. To the question in the questionnaire for students: "Do you attend classes with pleasure? $80 \%$ of the students answered, "no", not with pleasure, because we are taught to be objective, but in the 
real life we have the inadequate situations and we have to obey them.

In the first place they put the teacher's justice and objectivity, his/her intellect and mental qualities or ability to think, in the second - the methodology of training, skills to explain the new laws and its usage in the real life, in the third - the skill of assessment the student's knowledge level, in the fourth - the ability not to lock up within the education process, and continue to find the truth on the questions connected with law and justice.

Some essential questions were discussed at the teachers' seminar: "Practical training of scientific pedagogical staff in academic teachers' analysis" at Taras Shevchenko Kyiv National University, 2018.

Certainly, they pay attention to the teacher's appearance, his ability to keep up the audience and interest the students in mastering the discipline.

Some essential questions were discussed at the Interuniversity scientific and methodological seminar: "Actual problems of foreign language training of foreign specialists in the field of national security" at the Military Diplomatic Academy named after Yevheniy Berezniak, April 2018; International scientific and practical conference: "Service in the condition of global competition: legal and institutional dimensions" at Kyiv National University of Trade and Economics, November 2020

The research results of objectivity in the teacher's pedagogy activity have been discussed at the international conferences and some aspects have been observed in magazines.

Conclusions. Summarizing our thoughts above, it would be emphasized that justice is a law sensation that dictates a person to strive for what belongs to him/her. But to grasp justice as an internal aspect - it is necessary that a person, first of all, strong and powerful, the justice sensation does not develop to the apogee. On the contrary - it translated from the law sensation to duty, not only to take, but to give. In the mind there must be a need to seek all means to refuse at least some of the rights of their own pleasure for the common good. Justice and understanding between people are possible not when a strong person, nation or state enforces a coercively different recognition of their rights that they may find unfair and incomprehensible, and when they develop a sensation of solidarity that transforms a sensation of justice, make it more distinct not for their own rights, but for improving the situation of others.

Thus, the ideals of justice are truly revealed on the basis of the high beginnings of humanity, truthfulness, the desire for harmony of conscience with the laws of God: do not jealous, do not be envy, drive away arrogance - a close friend of pride.

References

Plato's tripartite theory of soul. (2018). / Available at: https://en.wikipedia.org/ wiki/Plato \%27s_tripartite_theory_of_soul

Political Theory - Confucius on the proper role of government. (2018) Available at: http://selfdeprecate.com/politics-articles/confucius-proper-rolegovernment/

Vasyanovych G. V. (2005). Pedagogical Ethics: teaching method. - Lviv: "Norma", $344 \mathrm{p}$

Zvarych I. M. (2015). Theoretical and Methodological Basic of Assessment the Lecturers' Pedagogic Activities at the USA's Higher Education Institutions. Kyiv: Fenix, pp: 144

Hegel G. The spirit of Christianity and its fate. (1976). Philosophical religions in Vol. I - II, V I. K: Mysl, p. 101-102

Надійшла до редколегії 06.03.21

Ірина Зварич, д-р пед. наук, профр.

ORCID iD:0000-0003-0715-9551

Київський національний торговельно-економічний університет, Київ, Україна

\section{ОБ'ЄКТИВНІСТЬ ПЕДАГОГІЧНОЇ ДІЯЛЬНОСТІ ВИКЛАДАЧІВ У ПРОЦЕСІ НАВЧАННЯ}

Висвітлено основну роль підготовки фахівців, зокрема, проблему діяльності педагогів, справедливість у процесі оцінювання якості знань студентів, що вказує на основну мету освіти - підеотувати молодь до повсякденного життя та майбутньої творчої діяльності. Освіта як основа розвитку держави і відзеркалення інтересів суспільства виконує соціальне замовлення - формує суспільний попит на знання і перспективи розвитку, вона змінюється під впливом часових, соціальних, економічних та інших факторів. Особливе місце в процесі підготовки фахівиів до корисної праці посідає проблема педагогічної діяльності викладача, зокрема ефективність викладання навчальних дисциплін, підвищення якості навчального процесу та забезпечення освітніх послуг, від яких істотно залежить успіх та результат у досягненні знань. Незважаючи на значну кількість наукової літератури щодо проблеми педагогічної діяльності, залишається суттєвою необхідність осмислення справедливості педагогічної діяльності у процесі навчання, зокрема у професійній підготовці фахівців. Метою дослідження є зосередити увагу на об'єктивності педагогічної діяльності викладачів у процесі навчання в університетах та показати зв'язок цієї проблеми з філософським вченням. Методологічною основою дослідження є вихідні положення філософії про діалектичні взаємозв 'язки, взаємозалежність явищ і процесів соціально-педагогічної діяльності, роль особистості у розвитку ії матеріальних і духовних основ. У науковому дослідженні використано системний підхід для виявлення маситабності, складності, цілісності та динаміки вивчення об'єктивності педагогічної діяльності викладачів у процесі навчання (за Г. П. Васяновичем). Ідею об'єктивності розвинули філософьи Платон, Фома Аквінський, Марк Тулія Цицерон, Конфуцій, Г. Гегель.

Ключові слова: об'єктивність, реформування, діяльність викладача, якість рівня знань студентів, освіта, внз, оцінка. 